\title{
Agronomic Evaluation and Genetic Characterization of Different Accessions in Lentil (Lens culinaris Medik.)
}

\author{
Monica Bacchi, Maria Leone, Francesco Mercati, Giovanni Preiti, \\ Francesco Sunseri, Michele Monti \\ Dipartimento di Biotecnologie per il Monitoraggio Agro-alimentare ed Ambientale, \\ Università degli Studi Mediterranea di Reggio Calabria \\ Salita Melissari, 89124 Reggio Calabria, Italy
}

Received: 4 February 2010. Accepted: 14 March 2010.

\begin{abstract}
Lentil is an important winter-sown legume for semi-arid and temperate areas, food consumption of seed is considerable in several countries of Mediterranean Basin. In Central and Southern Italy different lentil landraces are cultivated within specific marginal areas and commercialized with a recognizable geographical indication of origin. Considering the extensive germplasm and the economic importance of lentil in several rural areas, detailed knowledge of existing genetic variation from different regions is the first important step both for conservation and exploitation of genetic resources, allowing to develop breeding programs.

In field experiments over three cropping seasons (2002-2005), 25 lentil accessions from Plant Genetic Institute of National Research Council (Bari), representing part of a large germplasm collection from different areas, were carried out at the University of Reggio Calabria in order to characterize the agronomic performances in a semi-arid environment and to study genetic variability. For this purpose, 10 AFLP primer combinations and 6 SSR markers were used.

The agronomic results highlighted the influence of different climatic conditions on phenological, biometrical and yielding traits. A considerable production level of lentil $\left(2,55 \mathrm{t} \mathrm{ha}^{-1}\right)$ and a low yield variability in the three years was observed, showing the high adaptability of the germplasm tested to semi-arid environment. The earliness and the plant height appeared as the most important traits negatively correlated to grain yield; in particular the earliness was confirmed as suitable mechanism of escape from abiotic stress.

Genetic characterization showed that a few number of microsatellites and primer combinations are able to provide significant insights on genetic diversity combining the 25 accessions in 3 large clusters that mainly mirror their geographic origin. Principal Component Analysis that consider genetic as well as morphological and agronomic data allowed the discrimination of groups with higher similarity and the Laird variety was far from all the other accessions. The macrosperma accession MG 106401 from Algeria results the closest to Laird because of their late-flowering. The fingerprinting of these elite genotypes and the evaluated suitability of agronomic traits could usefully represent strategic tools for new targeted lentil breeding programs in Mediterranean area.
\end{abstract}

Key-words: agronomic performances, landraces, genetic diversity, yield components, AFLP, SSR.

\section{Introduction}

The genus Lens Miller is included in the Vicieae tribe with four diploid $(2 \mathrm{n}=14)$ species, L. culinaris ssp. culinaris (cultivated) which is sympatric with L. culinaris ssp. orientalis (wild), $L$. odemensis, L. nigricans and L. ervoides (Ladizinsky, 1993). Both the cultivated and wild species are native to parts of Asia, Africa and the Mediterranean (Mayer \& Soltis, 1994). Cultivated lentil (Lens culinaris Medik.) is a self-pol- linating annual crop, important throughout Western Asia, Northern Africa, Indian subcontinent and North America (Webb and Hawtin 1981; Erskine 1997). Lentil, together with wheat and barley, has hold a crucial function in the expansion and statement of Mediterranean-type agriculture, becoming an important protein source in the human diet. In world production grain legumes rank third behind cereals and oilseed crops, playing an essential role as a 
break crop that provides biologically fixed nitrogen in low input agrosystems, mainly on small-scale farms (Graham and Vance, 2003). Three millions and seventy-five thousands hectares are cultivated with lentil worldwide, with a production of 3.545 .000 ton and a main yield of about 0.9 ton per hectare (FAOSTAT, 2008). The lentil growing has undergone a rapid decline in Italy, as decreasing from 20.000 ha in the sixties to 1.816 ha in 2008 (FAOSTAT, 2008). As consequence, Italy annually imports about 28.000 tons of grain lentil for its internal consumption (FAOSTAT, 2007). Several causes contributed to this decline as a low and variable grain yield, a high production cost for the absence of modern agricultural techniques, the depopulation of farmed lands, and finally the lack of researches to exploit and improve the most appreciated landraces (Bacchi and D'Alessandro, 1996, Piergiovanni, 2000; Venora et al., 2007; Gallo et al., 2009; Piergiovanni et al., 2009).

Notwithstanding, the leguminous should be reconsidered for its agro-ecologic role in marginal agrosystems, as good adaptable species in dry areas (Monti et al., 1995), and for its nutritional grain quality (Howieson et al., 2000). Furthermore, the important role of pulses in the eco-sustainable agriculture is amplified in the organic farms, because of restoration and maintenance of fertility in degraded soils (Tallarico et al., 2003; Gresta et al., 2009; Pacucci et al., 2009).

Recently several classes of molecular markers have been developed showing that lentil has relatively low levels of genetic variation (Eujayl et al., 1997; Sonnante and Pignone, 2001). The polymerase chain reaction (PCR) technique have allowed to develop first of all RAPD (Randomly Amplified Polymorphic DNA) markers (Welsh and McClelland, 1990; Williams et al., 1990) useful to characterize several grain legume species (e.g. Menéndez et al., 1997; Eujayl et al., 1998; Santra et al., 2000). AFLP (Amplified Fragment Length Polymorphisms) technique, based on PCR, is characterized by a high degree of marker utility arising from its high multiplex ratio (Powell et al., 1996). RAPD and AFLP are now useful both for characterize germplasm collection and for construct saturated maps in this species (Eujayl et al., 1998; Rubeena et al., 2003; Duran et al., 2004; Fiocchetti et al., 2009). Inter-Simple Sequence Re- peats (ISSR), that utilize microsatellite sequences to design primers in PCR analyses (Gupta et al., 1994), have been used in lentil to evaluate genetic variation in several germplasm collections (Zàvodnà et al., 2000; Sonnante and Pignone, 2001; 2007). Finally, microsatellites or Simple Sequence Repeats (SSR) are reported as the ideal genetic marker considering that are abundant, polymorphic and reproducible and, in addition, they usually fit a co-dominant Mendelian inheritance (Morgante and Olivieri, 1993). Microsatellite markers have been developed in several crop species, including legume species such as lentil (Zàvodnà et al., 2000; Hamwieh et al., 2005), common bean (Hamann et al., 1995; Yu et al., 2000), and soybean (Akkaya et al., 1995; Powell et al., 1996). Therefore, the use of molecular markers is crucial for characterizing germplasm collections, taking into account that morphological traits are not sufficient to identify all different accessions.

In the present paper 22 selected landraces from lentil germplasm collection maintained at Plant Genetics Institute (National Research Council - CNR - Bari) were evaluated for morphologic traits and agronomic performances. The 22 entries had been previously selected by field experiments from a larger collection of 231 landraces (Di Prima et al., 1997, Monti et al., 1999; Anastasi et al., 2007). All genotypes were also characterized with AFLP and SSR markers with the aim to obtain the genetic distances among them that could support the choice of parental genotypes for breeding programs in marginal areas.

\section{Materials and methods}

\section{Plant material}

A comparison among 25 lentil genotypes, including 22 landraces from the collection maintained at Plant Genetics Institute (CNR-Bari), 1 commercial variety (Laird) and 2 improved lines, previously selected for grain yield, from the ICARDA's Lentil International Screening Nursery (LISN-S-1994) was carried out. The variety and the two ICARDA lines were used as testers and outgroup in agronomic and genetic assessments, respectively. Eighteen out of 25 accessions, many of which coming from the Mediterranean Basin, belong to the microsper- 
ma subspecies, while the remaining seven to the macrosperma subspecies (Tab. 1).

\section{Field experiments}

The field experiments was carried out, during the growing seasons 2002-03, 2003-04 and 200405 , at the experimental farm of the University of Reggio Calabria located in Gallina ( $38^{\circ} 10^{\prime}$ N., $15^{\circ} 45^{\prime}$ E., $232 \mathrm{~m}$ a.s.l). The farming soil, classified as 'Typic Haploxeralfs' (USDA), has the following physical-chemical and hydrological features: sand $51.5 \%$, clay $33.1 \%$, silt $15.4 \%$, reaction $6.8(\mathrm{pH}$ in water), organic matter $1.1 \%$ (Lotti), total $\mathrm{N} 0.9 \%$ (Kjeldhal), assimilable $\mathrm{P}_{2} \mathrm{O}_{5} 16.7$ ppm (Olsen), exchangeable $\mathrm{K}_{2} \mathrm{O} 284.5$ ppm (ammonium acetate); field capacity and wilting point respectively $30.3 \%$ and $17.2 \%$ in dry weight.

The soil, previously cultivated with wheat, was prepared for sowing by ploughing in summer to a depth of $30 \mathrm{~cm}$, followed in autumn by harrowing. Before sowing $20 \mathrm{Kg} \mathrm{ha}^{-1}$ of $\mathrm{N}$ as "starter" and $100 \mathrm{Kg} \mathrm{ha}^{-1}$ of $\mathrm{P}_{2} \mathrm{O}_{5}$ were applied. Sowing was carried out manually during the sec-

Table 1. List of lentil accessions evaluated in this study.

\begin{tabular}{lll}
\hline Accession No. & Origin & Material type \\
\hline MG 106401* & Algeria (Al)** & Landrace \\
MG 106365 & Algeria (Al) & Landrace \\
MG 107516 & Algeria (Al) & Landrace \\
MG 112366 & Cyprus (Cy) & Landrace \\
\hline MG 112377 & Cyprus (Cy) & Landrace \\
MG 112374 & Cyprus (Cy) & Landrace \\
MG 110830 & Egypt (Eg) & Landrace \\
MG 111819 & Egypt (Eg) & Landrace \\
MG 111820 & Egypt (Eg) & Landrace \\
MG 116218 & Italy (It) & Landrace \\
MG 116219 & Italy (It) & Landrace \\
MG 116221 & Italy (It) & Landrace \\
MG 111909 & Libya (Li) & Landrace \\
MG 112114 & Morocco (Mo) & Landrace \\
MG 112163 & Morocco (Mo) & Landrace \\
MG 106692 & Tunisia (Tu) & Landrace \\
MG 106746 & Tunisia (Tu) & Landrace \\
MG 107386 & Pakistan (Pa) & Landrace \\
MG 107420 & Pakistan (Pa) & Landrace \\
MG 106309 & Ethiopia (Et) & Landrace \\
MG 106315 & Ethiopia (Et) & Landrace \\
MG 106353 & Ethiopia (Et) & Landrace \\
ILL 7202 & Icarda (Ic) & Improved line \\
ILL 7535 & Icarda (Ic) & Improved line \\
Laird & Canada (Ca) & Commercial variety \\
\hline
\end{tabular}

* the underlined genotypes belong to subspecies macrosperma.

${ }^{* *}$ in the bracket the abbreviation for the country of origin. ond decade of December in plots of $9 \mathrm{~m}^{2}(1.8$ $\mathrm{m} \times 5 \mathrm{~m}$ ) in rows of $30 \mathrm{~cm}$ apart, sowing density was 200 germinable seeds per $\mathrm{m}^{-2}$. Weeds were controlled manually before the canopy was closed. Harvesting was carried out in June at $75 \%$ of the ripeness.

The following traits were recorded: number of plants at emergence, flowering time (days after sowing - das), plant height and first fertile pod insertion, and grain yield were measured onto two central rows of each plot; while pods per plant, seeds per pod and seeds weight were measured on a sample of ten plants for each plot. A randomized blocks experimental design with three replications was adopted. Considering the different temperature-rainfall trends during the field experiments, the year was included in analysis of variance as random factor, and after evaluating the homogeneity of variances (Bartlett test), a combined analysis over threeyear was performed. The Student-Newman-Keuls test was used to compare means of genotypes. Finally, the relationships between phenological, biometric and productive traits were examined using simple correlation analysis.

\section{Genetic analysis}

The 25 accessions were characterized for genetic variability using two different classes of molecular markers AFLP and microsatellites. DNA extraction was carried out using young leaves kept at $-80{ }^{\circ} \mathrm{C}$. The DNA was isolated from $2 \mathrm{~g}$ of plant tissue, powdered using a mortar and pestle in liquid nitrogen. Total DNA was isolated using the CTAB (hexadecyltrimethylammonium bromide - Sigma) method following the protocol reported by Doyle and Doyle (1987) and modified by Rowland and Nguyen (1993) taking into account the omission of the precipitation in polyethylene glycol. The DNA concentration was estimated using electrophoresis with $1 \%$ agarose gel, and the $\lambda$ DNA as a marker. The electrophoresis running using a constant voltage and the gel, placed on an ultraviolet trans-illuminator, has been photographed.

AFLP protocol (Vos et al., 1995), using the method with fluorescent primers, was carried out according to Aggarwal et al. (2002), with minor modifications. Total genomic DNA was digested with an EcoRI/MseI restriction enzymes combination and specific double-stranded adap- 
Table 2. AFLP primer combinations utilized on 25 lentil accessions.

\begin{tabular}{lccc}
\hline $\begin{array}{l}\text { Primer } \\
\text { combination* }\end{array}$ & $\begin{array}{c}\text { Total } \\
\text { fragment } \\
\text { No. }\end{array}$ & $\begin{array}{c}\text { Polymorphic } \\
\text { fragment } \\
\text { No. }\end{array}$ & $\begin{array}{c}\text { Polymorphic } \\
\text { fragment } \\
\%\end{array}$ \\
\hline P11 + M47 & 53 & 13 & 24.5 \\
P11 + M48 & 42 & 9 & 21.4 \\
P11 + M49 & 41 & 7 & 17.1 \\
E32 + M47 & 55 & 16 & 29.1 \\
E32 + M48 & 40 & 8 & 20.0 \\
E32 + M50 & 43 & 12 & 27.9 \\
E35 + M50 & 55 & 20 & 36.4 \\
E35 + M59 & 39 & 10 & 25.6 \\
E35 + M60 & 38 & 9 & 23.7 \\
E35 + M62 & 47 & 13 & 27.7 \\
\hline Total & 453 & 117 & 25.8 \\
\hline
\end{tabular}

*Abbreviations indicate the restriction enzymes $(\mathrm{P}=$ PstI $\mathrm{E}=\mathrm{EcoRI} \mathrm{M}=\mathrm{Mse} \mathrm{I}$ )

the numbers are the extension bases considering an International Code.

tors were ligated to fragment ends. Pre-amplification was performed with 1-bp extension primers (MseI primer+C; EcoRI primer $+\mathrm{A}$ ). Selective amplification of restriction fragments was performed using primers with 3-bp selective nucleotides. Ten primer combinations were used to screen for polymorphism among the samples (Tab. 2). At the end of the reaction 0.5$1.0 \mu \mathrm{l}$ of each sample was analyzed on ABI PRISM 3130 (Applied Biosystems) genetic analyzer. Electropherograms in the 100-500 bp range were then analyzed to classify the polymorphic bands (peaks). Genetic characteriza- tion was also carried out with SSR markers using the primers listed in Table 3, the PCR condition in order to obtain the amplicons were reported on Hamwieh et al., 2005. One of the primers of each pair was marked (fluorescent) with the fluorochromes FAM, JOE or TAMRA, the fragments obtained were separated by ABI PRISM 3130 (Applied Biosystems). The data obtained from 6 microsatellite loci (Hamwieh et al., 2005) allowed to calculate the probability of finding different genotypes with the same profile and several genetic parameters such as number of alleles, expected and observed heterozygosity by using IDENTITY software version 1.0 (Wagner and Sefc, 1999). An output matrix (0, 1) based on the presence or absence of each specific amplified AFLP fragment was obtained. The matrix for SSR was obtained considering the alleles for each SSR locus in all the genotypes analyzed. Matrices from AFLP and SSR was analyzed by a statistical correlation test (Mantel, 1967) showing a highly significant $\mathrm{R}^{2}$ (0.89). Genetic distances were calculated for all pairs of genotypes using the Simple Match coefficient and cluster analysis was carried out and UPGMA (Unweighted Pair-Group Method with Arithmetical Averages) algorithm utilizing NTSYS-PC package software version 2.02 (Rohlf, 1998). Cluster branch stability was analyzed by means of a resampling method with 1,000 bootstraps. Bootstrap analysis and Mantel Test were performed by the PAST software

Table 3. Primer SSR utilized in the microsatellite experiments carried out on lentil (from Hamwieh et al., 2005).

\begin{tabular}{|c|c|c|c|c|}
\hline Name & Primer sequence $\left(5^{\prime} \rightarrow 3^{\prime}\right)$ & Repeats & $\begin{array}{l}\text { Expected size } \\
\text { (bp) }\end{array}$ & $\begin{array}{c}\text { Annealing } \\
\text { temperature }\left({ }^{\circ} \mathrm{C}\right)\end{array}$ \\
\hline SSR 107 for & GCGGCGAGCAAATAAAT & $\begin{array}{l}(\mathrm{TC})_{9}+(\mathrm{AT})_{5} \mathrm{C}(\mathrm{AT})_{3} \\
\quad(\mathrm{GT})_{14} \mathrm{~A}(\mathrm{TG})_{7}^{\mathrm{a}}\end{array}$ & 168 & 51 \\
\hline SSR 107 rev & GGAGAATAAGAGTGAAATG & & & \\
\hline SSR 113 for & CCGTAAGAATTAGGTGTC & $(\mathrm{AC})_{17}(\mathrm{AT})_{13}$ & 211 & 51 \\
\hline SSR 113 rev & GGAAAATAGGGTGGAAAG & & & \\
\hline SSR 323 for & AGTGACAACAAAATGTGAGT & $(\mathrm{AT})_{22}(\mathrm{CA})_{4}$ & 250 & 51 \\
\hline SSR 323 rev & GTACCTAGTTTCATCATTG & & & \\
\hline SSR 156 for & GTACATTGAACAGCATCATC & $(\mathrm{TC})_{2}(\mathrm{TG})_{13}$ & 176 & 53 \\
\hline SSR 156 rev & CAAATGGGCATGAAAGGAG & & & \\
\hline SSR 204 for & CACGACTATCCCACTTG & $(\mathrm{TG})_{4}+(\mathrm{AC})_{7}^{\mathrm{b}}$ & 186 & 53 \\
\hline SSR 204 rev & СТTACTTTCTTAGTGCTATTAC & & & \\
\hline SSR $317-2$ for & CACGTAACATCTTGCTTATG & $\begin{array}{c}(\mathrm{TTG})_{2}(\mathrm{AT})_{2} \mathrm{~A}(\mathrm{AT})_{2} \\
\mathrm{G}(\mathrm{TA})_{14} \mathrm{ATC}(\mathrm{GT})_{4}\end{array}$ & 120 & 53 \\
\hline
\end{tabular}

a (TC) $)_{9}$ TATCGATCATCTG(AT) $)_{5} \mathrm{C}(\mathrm{AT})_{3}(\mathrm{GT})_{14} \mathrm{~A}(\mathrm{TG})_{7}$

b (TG) ${ }_{4}$ CTTAAGCCTAGGTAGGAGGCTTATCTCTCAAGTAAAACACCCATAACCTAACAAT(AC) ${ }_{7}$ 
(Hammer et al., 2001). Principal component analysis (PCA) was finally carried out taking into account the data from agronomic evaluation (average of the three-year) and the genetic distance matrix obtained from SSR and AFLP data. It was not possible to depict an unique dendrogram starting from agronomic and genetic data due to a non statistically significant $\mathrm{R}^{2}$ value in the performed Mantel Test (Mantel, 1967).

\section{Results and discussion}

\section{Climatic data}

Differences in climatic trends during the 3 cropping seasons are shown in Table 4. The thermal trend over the three years was similar to the plurennial mean: temperature never below $5{ }^{\circ} \mathrm{C}$ in the coldest months, except in February in the first year, and maximum temperature, on average, above $20{ }^{\circ} \mathrm{C}$ from May onwards. It is important to emphasize the very high temperatures during ripening in 2003. The rainfall was characterized by a high variability, overall in distribution. The fifteen-year mean rainfall at the experimental site was $527 \mathrm{~mm}$, much less than total annual precipitation over the studied period.

\section{Field experiments}

The average plant density was 182 , slightly less than the planned number (Tab. 5). The number of plants per $\mathrm{m}^{-2}$ at harvest was higher for $m i$ cro- compared to macro types. Among microsperma, MG 116218 (Italy) and MG 106746
(Tunisia) had the highest plant density, closest to the planned number (196 and 194 plants per $\mathrm{m}^{-2}$, respectively), while the macrosperma $\mathrm{MG}$ 106401 (Algeria) and Laird (158 and 164 plants per $\mathrm{m}^{-2}$ respectively) resulted considerably lower than other accessions.

As showed in Table 5, agronomic performances were significantly affected by different climatic conditions. The mean value of earliness was 127 days after sowing, the lowest and highest values were observed in the accession MG106309 (Ethiopia) (121 das) and in the Laird variety (142 das), respectively; microsper$m a$ accessions showed a greater earliness $(-5$ days) than macrosperma. Flowering time was negatively correlated with grain yield $(\mathrm{r}=$ $0.521 ; \mathrm{P} \leq 0.01$ ) confirming the importance of this trait in semi-arid environment for the adaptation to abiotic stress.

Microsperma MG 107420 from Pakistan showed the lowest mean value $(36.6 \mathrm{~cm})$ for plant height and Laird variety the highest one $(58.0 \mathrm{~cm})$. This trait was higher in macrosperma accessions than microsperma; macrosperma mean value was influenced by the presence in this group of Laird variety that was $15 \mathrm{~cm}$ taller compared to the mean of the field.

Mean height of the first fertile pod was 24.2 $\mathrm{cm}$, following the same trend of plant height: higher values in macro than micro types were recorded. Laird variety had the highest mean value $(41.6 \mathrm{~cm})$, significantly higher than $\mathrm{MG}$ 106401 (Algeria), MG 112366 and MG 112377 (both from Cyprus) belonging to the macros-

Table 4. Weather condition (monthly means) during the three cropping seasons (2002-2005), and the long-term average (1991-2005).

\begin{tabular}{lccccccccc}
\hline & October & November & December & January & February & March & April & May & June \\
\hline Minimum $T .\left({ }^{\circ} \mathrm{C}\right)$ & & & & & & & & & \\
2002/03 & 15.3 & 13.3 & 9.8 & 8.7 & 4.7 & 7.2 & 10.1 & 15.9 & 21.0 \\
2003/04 & 13.9 & 13.5 & 9.6 & 7.3 & 7.9 & 8.3 & 11.3 & 12.7 & 18.4 \\
2004/05 & 17.4 & 11.8 & 10.8 & 6.4 & 5.4 & 8.5 & 9.8 & 15.0 & 18.8 \\
15-years average & 16.2 & 12.3 & 9.4 & 7.1 & 6.7 & 8.2 & 10.0 & 14.5 & 18.9 \\
Maximum T. $\left({ }^{\circ} \mathrm{C}\right)$ & & & & & & & & & \\
2002/03 & 22.3 & 19.3 & 14.2 & 14.1 & 11.0 & 14.2 & 17.6 & 24.0 & 30.3 \\
2003/04 & 21.3 & 19.6 & 14.6 & 12.6 & 14.1 & 14.7 & 17.9 & 20.9 & 27.2 \\
2004/05 & 24.7 & 18.4 & 15.8 & 12.2 & 12.1 & 16.1 & 17.2 & 23.4 & 26.8 \\
15-years average & 22.9 & 18.0 & 14.3 & 13.1 & 13.3 & 16.6 & 18.0 & 23.3 & 28.1 \\
Rainfall (mm) & & & & & & & & & \\
2002/03 & 38.6 & 42.2 & 260.4 & 93.7 & 62.2 & 41.4 & 97.8 & 43.2 & 6.9 \\
2003/04 & 89.7 & 106.3 & 154.7 & 59.4 & 10.1 & 101.6 & 43.2 & 16.8 & 36.4 \\
2004/05 & 10.3 & 70.5 & 168.5 & 61.0 & 50.9 & 63.4 & 77.0 & 89.7 & 20.8 \\
15-years average & 64.3 & 68.4 & 107.5 & 89.8 & 58.2 & 46.6 & 47.4 & 31.6 & 13.5 \\
\hline
\end{tabular}


Bacchi M., Leone M., Mercati F., Preiti G., Sunseri F., Monti M.

Table 5. Morphological and agronomic traits observed on 25 genotypes of lentil.

\begin{tabular}{|c|c|c|c|c|c|c|c|}
\hline $\begin{array}{l}\text { Accession } \\
\text { No. }\end{array}$ & $\begin{array}{c}\text { Plant } \\
\text { density } \\
\left(\text { No. } \mathrm{m}^{-2}\right)\end{array}$ & $\begin{array}{l}\text { Flowering } \\
\text { (das) }\end{array}$ & $\begin{array}{l}\text { Plant } \\
\text { height } \\
(\mathrm{cm})\end{array}$ & $\begin{array}{l}\text { First pod } \\
\text { height } \\
(\mathrm{cm})\end{array}$ & $\begin{array}{l}\text { Pods } \\
\text { plant } \\
\text { (No.) }\end{array}$ & $\begin{array}{l}\text { Seeds } \\
\text { pods } \\
(\text { No. })\end{array}$ & $\begin{array}{c}1000 \text { Seed } \\
\text { weight } \\
(\mathrm{g})\end{array}$ \\
\hline MG 106401 (Al) & $158 \mathrm{~J}$ & $139 \mathrm{~B}$ & $51.3 \mathrm{~B}$ & $30.8 \mathrm{~B}$ & $30.0 \mathrm{I}$ & $1.02 \mathrm{I}$ & $66.2 \mathrm{~A}$ \\
\hline MG 106365 (Al) & $185 \mathrm{DF}$ & $126 \mathrm{EF}$ & $40.5 \mathrm{FG}$ & $23.2 \mathrm{FG}$ & $35.9 \mathrm{EH}$ & $1.56 \mathrm{~B}$ & $31.0 \mathrm{I}$ \\
\hline MG 107516 (Al) & $187 \mathrm{CF}$ & $126 \mathrm{EF}$ & $39.3 \mathrm{G}$ & $21.7 \mathrm{GJ}$ & $48.6 \mathrm{~A}$ & $1.62 \mathrm{~A}$ & $25.1 \mathrm{~L}$ \\
\hline MG 112366 (Cy) & $174 \mathrm{H}$ & $129 \mathrm{D}$ & $43.8 \mathrm{CD}$ & $29.5 \mathrm{~B}$ & $37.4 \mathrm{DG}$ & $1.04 \mathrm{I}$ & $53.7 \mathrm{C}$ \\
\hline MG 112377 (Cy) & $177 \mathrm{GH}$ & $126 \mathrm{EF}$ & $50.3 \mathrm{~B}$ & $30.5 \mathrm{~B}$ & $28.6 \mathrm{IJ}$ & $1.07 \mathrm{I}$ & $47.0 \mathrm{D}$ \\
\hline MG 112374 (Cy) & $185 \mathrm{DF}$ & $127 \mathrm{EF}$ & $44.2 \mathrm{CD}$ & $27.3 \mathrm{C}$ & $27.7 \mathrm{IJ}$ & $1.20 \mathrm{H}$ & $46.4 \mathrm{D}$ \\
\hline MG 110830 (Eg) & $180 \mathrm{FG}$ & $128 \mathrm{E}$ & 43.6 CD & $19.7 \mathrm{~J}$ & $38.2 \mathrm{DF}$ & $1.48 \mathrm{BE}$ & $28.0 \mathrm{~K}$ \\
\hline MG 111819 (Eg) & $180 \mathrm{FG}$ & $127 \mathrm{EF}$ & $42.3 \mathrm{DF}$ & $19.9 \mathrm{IJ}$ & $35.2 \mathrm{FH}$ & $1.46 \mathrm{CE}$ & $29.2 \mathrm{JK}$ \\
\hline MG $111820(\mathrm{Eg})$ & $178 \mathrm{GH}$ & $128 \mathrm{E}$ & $42.9 \mathrm{CE}$ & $21.1 \mathrm{GJ}$ & $39.3 \mathrm{DE}$ & $1.49 \mathrm{BE}$ & $27.9 \mathrm{~K}$ \\
\hline MG 116218 (It) & $196 \mathrm{~A}$ & $127 \mathrm{EF}$ & 41.2 EG & $21.8 \mathrm{GJ}$ & $26.1 \mathrm{~J}$ & $1.62 \mathrm{~A}$ & $30.3 \mathrm{IJ}$ \\
\hline MG 116219 (It) & $183 \mathrm{EG}$ & $124 \mathrm{GI}$ & $43.9 \mathrm{CD}$ & $24.0 \mathrm{EF}$ & $26.0 \mathrm{~J}$ & $1.55 \mathrm{~B}$ & $34.1 \mathrm{G}$ \\
\hline MG 116221 (It) & $185 \mathrm{DF}$ & $126 \mathrm{FG}$ & 44.1 CD & $24.5 \mathrm{EF}$ & $30.6 \mathrm{I}$ & $1.64 \mathrm{~A}$ & $29.2 \mathrm{JK}$ \\
\hline MG $111909(\mathrm{Li})$ & $185 \mathrm{DF}$ & $125 \mathrm{FH}$ & $39.6 \mathrm{G}$ & $20.2 \mathrm{IJ}$ & $38.3 \mathrm{DF}$ & $1.50 \mathrm{BD}$ & $23.8 \mathrm{LM}$ \\
\hline MG 112114 (Mo) & $189 \mathrm{BE}$ & $126 \mathrm{EF}$ & 43.6 CD & $25.2 \mathrm{DE}$ & $42.4 \mathrm{BC}$ & $1.23 \mathrm{H}$ & $43.2 \mathrm{E}$ \\
\hline MG 112163 (Mo) & $192 \mathrm{AC}$ & $126 \mathrm{EF}$ & $44.8 \mathrm{C}$ & $25.4 \mathrm{DE}$ & $36.1 \mathrm{EH}$ & $1.30 \mathrm{G}$ & $43.3 \mathrm{E}$ \\
\hline$\overline{\mathrm{MG} 106692(\mathrm{Tu})}$ & $178 \mathrm{GH}$ & $126 \mathrm{EF}$ & $40.4 \mathrm{FG}$ & $22.7 \mathrm{FH}$ & $38.2 \mathrm{DF}$ & $1.52 \mathrm{BC}$ & $22.2 \mathrm{MN}$ \\
\hline MG 106746 (Tu) & $194 \mathrm{AB}$ & $126 \mathrm{EF}$ & $39.2 \mathrm{G}$ & $21.1 \mathrm{GS}$ & $43.7 \mathrm{~B}$ & $1.52 \mathrm{BC}$ & $21.5 \mathrm{~N}$ \\
\hline MG $107386(\mathrm{~Pa})$ & $191 \mathrm{AD}$ & $126 \mathrm{EF}$ & $39.7 \mathrm{G}$ & $22.0 \mathrm{GI}$ & $38.3 \mathrm{DF}$ & $1.43 \mathrm{E}$ & $22.9 \mathrm{MN}$ \\
\hline MG $107420(\mathrm{~Pa})$ & $182 \mathrm{FG}$ & $137 \mathrm{C}$ & $36.6 \mathrm{H}$ & $23.2 \mathrm{FG}$ & $26.2 \mathrm{~J}$ & $1.54 \mathrm{~B}$ & $22.6 \mathrm{MN}$ \\
\hline MG 106309 (Et) & $181 \mathrm{FG}$ & $121 \mathrm{~K}$ & $39.1 \mathrm{G}$ & $19.9 \mathrm{IJ}$ & $35.7 \mathrm{EH}$ & $1.37 \mathrm{~F}$ & $32.5 \mathrm{G}$ \\
\hline MG 106315 (Et) & $182 \mathrm{FG}$ & $123 \mathrm{~J}$ & $42.8 \mathrm{CE}$ & $21.7 \mathrm{GJ}$ & $33.6 \mathrm{H}$ & $1.44 \mathrm{DE}$ & $34.3 \mathrm{G}$ \\
\hline MG $106353(\mathrm{Et})$ & $181 \mathrm{FG}$ & $124 \mathrm{HJ}$ & $43.6 \mathrm{CD}$ & $21.2 \mathrm{GS}$ & $34.0 \mathrm{GH}$ & $1.51 \mathrm{BD}$ & $30.7 \mathrm{IJ}$ \\
\hline ILL 7202 (Ic) & $184 \mathrm{DF}$ & $124 \mathrm{IJ}$ & $42.3 \mathrm{DF}$ & $26.3 \mathrm{CD}$ & $35.9 \mathrm{EH}$ & $1.35 \mathrm{FG}$ & $35.1 \mathrm{G}$ \\
\hline ILL 7535 (Ic) & $190 \mathrm{BE}$ & $124 \mathrm{HJ}$ & $40.4 \mathrm{FG}$ & $20.8 \mathrm{HJ}$ & $40.1 \mathrm{CD}$ & $1.34 \mathrm{FG}$ & $38.3 \mathrm{~F}$ \\
\hline Laird $(\mathrm{Ca})$ & $164 \mathrm{~L}$ & $142 \mathrm{~A}$ & $58.0 \mathrm{~A}$ & $41.6 \mathrm{~A}$ & $21.1 \mathrm{~K}$ & $1.03 \mathrm{I}$ & $63.3 \mathrm{~B}$ \\
\hline Mean & 182 & 127 & 43.1 & 24.2 & 34.7 & 1.39 & 35.3 \\
\hline ssp - macro & 177 & 131 & 48.0 & 30.0 & 31.9 & 1.13 & 51.9 \\
\hline ssp - micro & 185 & 126 & 41.2 & 21.9 & 35.8 & 1.50 & 28.8 \\
\hline
\end{tabular}

In each column values followed by the same letter are not significantly different at $\mathrm{P} \leq 0.01$ (capital letter); Student-Newman-Keuls test.

perma too. The height of both plant and first fertile pod are negatively correlated to grain yield $(\mathrm{r}=-0.448, \mathrm{P} \leq 0.05 ; \mathrm{r}=-0.467, \mathrm{P} \leq 0.05$ respectively).

The yield level of lentil in this environment, meanly over 2 tons per hectare in the triennium, showed the adaptability of tested genotypes to semi-arid environments of southern Italy. The mean value of accessions ranged between 2.94 and 1.66 $\mathrm{t} \mathrm{ha}^{-1}$ : the highest values were found for MG 112163 and MG 112114 (both from Morocco), MG 116218 (Italy) and MG 112374 (Cyprus) statistically similar among them. The Laird variety, selected for an environment different from the Mediterranean Basin, showed the lowest grain yield, always below $2 \mathrm{t} \mathrm{ha}^{-1}$. Variability in grain yield among genotypes was observed, but differences between macro and microsperma groups were not found; the yield level does not appear influenced by geographic origins (Fig. 1).

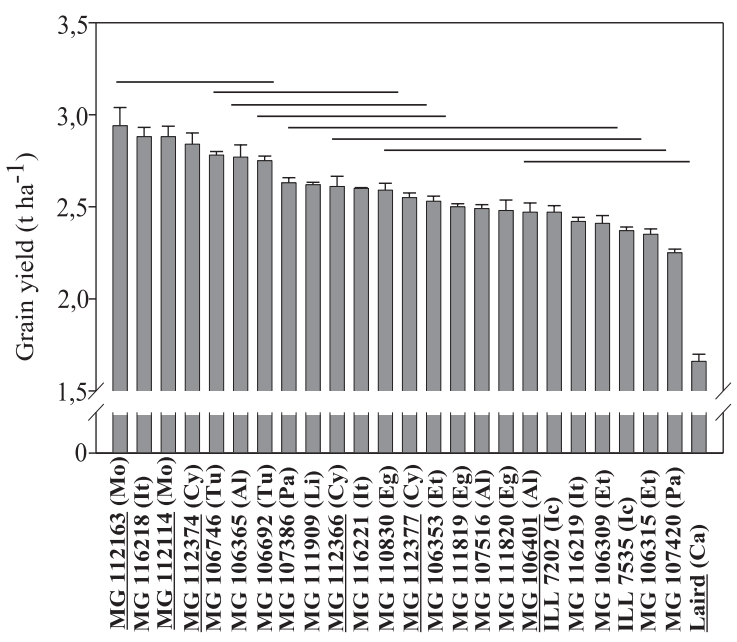

Figure 1. Grain yield of 25 tested genotypes of lentil (mean over three years). Vertical bars indicate \pm standard error of the mean. Horizontal lines indicate the SNK test. The underlined genotypes belongs to the macrosperma group. 
Pods per plant, mainly important in determining the grain yield (Preiti et al., 2009), were higher in microsperma (+3.9 micro vs. macro). The significantly highest value (48.6) was recorded for MG 107516 (Algeria). The landraces MG 106746 (Tunisia), MG 112114 (Morocco) and the improved lines ILL 7535 (ICARDA) showed a number of pods per plant higher than 40; Laird variety showed the lowest mean value (21.1). Pod per plant was the only yield components significantly correlated with grain yield $(\mathrm{r}=0.397, \mathrm{P} \leq 0.05)$.

Seeds per pod showed significant differences between genotypes and macro and micro types. Among all accessions values ranged from 1.64 in MG 116221 (Italy) to 1.02 in MG 106401 (Algeria). The lowest values, significantly not different among them, were recorded in 5 out of 7 macrosperma, including the Laird variety.

One thousand seeds weight (mean value 35.3 g) was higher in macrosperma than microsper$m a$ types (51.9 and $28.8 \mathrm{~g}$ respectively), as expected. Among macro types, values ranged from $43.2 \mathrm{~g}$ (MG 112114, Morocco) to $66.2 \mathrm{~g}$ (MG 106401, Algeria), in micro types from $21.5 \mathrm{~g}$
(MG 106746, Tunisia) to $38.3 \mathrm{~g}$ (ILL 7535, ICARDA), 1,000-seed weight was negatively correlated to seeds per pod $(\mathrm{r}=-0.896, \mathrm{P} \leq$ $0.01)$.

\section{Genetic characterization}

An average of approximately 45 fragments for primer combination were amplified and 117 out of $453(25.8 \%)$ were found to be polymorphic. The level of polymorphism identified (Tab. 2) is comparable to the first published data on lentil (Eujayl et al., 1998; Duran et al., 2004), but in contrast with a recent paper (Fiocchetti et al., 2009), that reports a higher percentage of polymorphic fragments.

The accessions were also tested with 6 microsatellites and 25 different genetic profiles were found (Tab. 6). This result was expected since the probability of finding different genotypes with the same profile is extremely low (Probability of Identity $=1.21 \times 10^{-6}$ ). The number of alleles (n), size range and allele frequency for each SSR locus are shown in Table 7. The total number of alleles per SSR locus varies from 3 to 14 with an average of 9.16. The main

Table 6. Genetic profiles of the accessions at the six microsatellite loci studied.

\begin{tabular}{|c|c|c|c|c|c|c|c|c|c|c|c|c|}
\hline $\begin{array}{l}\text { Accessions } \\
\text { number }\end{array}$ & $\begin{array}{c}\text { SSR } \\
107 \_1\end{array}$ & $\begin{array}{l}\text { SSR } \\
107 \_2\end{array}$ & $\begin{array}{l}\text { SSR } \\
113 \_1\end{array}$ & $\begin{array}{c}\text { SSR } \\
113 \_2\end{array}$ & $\begin{array}{l}\text { SSR } \\
323 \_1\end{array}$ & $\begin{array}{c}\text { SSR } \\
323 \_2\end{array}$ & $\begin{array}{c}\text { SSR } \\
\text { 317-2_1 }\end{array}$ & $\begin{array}{c}\text { SSR } \\
317-2 \_2\end{array}$ & $\begin{array}{l}\text { SSR } \\
156 \_1\end{array}$ & $\begin{array}{c}\text { SSR } \\
156 \_2\end{array}$ & $\begin{array}{c}\text { SSR } \\
204 \_1\end{array}$ & $\begin{array}{c}\text { SSR } \\
204 \_2\end{array}$ \\
\hline MG 106401 (Al) & 156 & 156 & 209 & 209 & 272 & 298 & 130 & 132 & 176 & 182 & 181 & 181 \\
\hline$\overline{\mathrm{MG} 106365}(\mathrm{Al})$ & 148 & 152 & 209 & 209 & 276 & 276 & 136 & 138 & 176 & 182 & 181 & 183 \\
\hline MG $107516(\mathrm{Al})$ & 148 & 148 & 211 & 217 & 288 & 288 & 128 & 134 & 176 & 182 & 181 & 183 \\
\hline MG 112366 (Cy) & 158 & 164 & 213 & 225 & 302 & 302 & 114 & 116 & 176 & 176 & 183 & 183 \\
\hline MG 112377 (Cy) & 156 & 156 & 213 & 225 & 302 & 302 & 124 & 124 & 176 & 176 & 183 & 183 \\
\hline MG 112374 (Cy) & 156 & 156 & 213 & 225 & 298 & 302 & 112 & 124 & 176 & 176 & 183 & 183 \\
\hline MG $110830(\mathrm{Eg})$ & 156 & 158 & 213 & 213 & 268 & 268 & 116 & 118 & 176 & 176 & 183 & 183 \\
\hline MG 111819 (Eg) & 156 & 156 & 213 & 213 & 268 & 268 & 114 & 116 & 176 & 176 & 183 & 183 \\
\hline MG $111820(\mathrm{Eg})$ & 156 & 158 & 209 & 213 & 274 & 274 & 114 & 118 & 176 & 176 & 183 & 183 \\
\hline MG 116218 (It) & 142 & 150 & 207 & 207 & 274 & 274 & 134 & 136 & 176 & 178 & 181 & 181 \\
\hline MG 116219 (It) & 154 & 154 & 223 & 227 & 274 & 298 & 114 & 132 & 176 & 178 & 181 & 183 \\
\hline MG 116221 (It) & 150 & 150 & 211 & 211 & 274 & 274 & 136 & 138 & 176 & 178 & 181 & 189 \\
\hline MG 111909 (Li) & 156 & 156 & 213 & 213 & 272 & 272 & 128 & 130 & 178 & 182 & 183 & 183 \\
\hline MG 112114 (Mo) & 158 & 158 & 215 & 219 & 272 & 292 & 118 & 120 & 176 & 182 & 185 & 189 \\
\hline 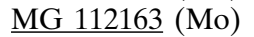 & 156 & 164 & 215 & 215 & 310 & 314 & 118 & 120 & 176 & 182 & 189 & 189 \\
\hline MG $106692(\mathrm{Tu})$ & 164 & 168 & 207 & 211 & 270 & 272 & 116 & 118 & 176 & 182 & 189 & 189 \\
\hline MG $106746(\mathrm{Tu})$ & 164 & 168 & 207 & 211 & 270 & 272 & 116 & 118 & 176 & 178 & 189 & 189 \\
\hline MG $107386(\mathrm{~Pa})$ & 168 & 168 & 235 & 235 & 268 & 268 & 116 & 118 & 178 & 182 & 189 & 189 \\
\hline MG $107420(\mathrm{~Pa})$ & 156 & 166 & 213 & 213 & 270 & 272 & 114 & 118 & 178 & 182 & 189 & 189 \\
\hline MG 106309 (Et) & 156 & 156 & 219 & 219 & 302 & 302 & 124 & 126 & 178 & 178 & 185 & 189 \\
\hline MG 106315 (Et) & 158 & 158 & 209 & 217 & 292 & 292 & 118 & 120 & 178 & 178 & 189 & 189 \\
\hline MG $106353(\mathrm{Et})$ & 164 & 168 & 219 & 219 & 292 & 292 & 120 & 122 & 178 & 178 & 185 & 189 \\
\hline ILL 7202 (Ic) & 158 & 168 & 225 & 225 & 272 & 274 & 118 & 120 & 176 & 178 & 189 & 189 \\
\hline ILL 7535 (Ic) & 158 & 158 & 221 & 221 & 272 & 272 & 128 & 130 & 176 & 178 & 189 & 189 \\
\hline$\underline{\text { Laird }(\mathrm{Ca})}$ & 164 & 164 & 223 & 223 & 304 & 304 & 114 & 118 & 176 & 178 & 181 & 189 \\
\hline
\end{tabular}


Bacchi M., Leone M., Mercati F., Preiti G., Sunseri F., Monti M.

Table 7. Genetic parameters obtained from 6 SSR loci analyzed on the 25 lentil accessions.

\begin{tabular}{lcccccc}
\hline Locus & $\begin{array}{c}\text { Allele } \\
\text { No. }\end{array}$ & $\begin{array}{c}\text { Allele } \\
\text { range size } \\
(\mathrm{bp})\end{array}$ & $\begin{array}{c}\text { Expected } \\
\text { heterozigosity } \\
\left(\mathrm{H}_{\mathrm{e}}\right)\end{array}$ & $\begin{array}{c}\text { Observed } \\
\text { heterozigosity } \\
\left(\mathrm{H}_{\mathrm{o}}\right)\end{array}$ & $\begin{array}{c}\text { Frequency } \\
\text { of null allele } \\
(\mathrm{r})\end{array}$ & $\begin{array}{c}\text { Probability } \\
\text { identity } \\
(\mathrm{PI})\end{array}$ \\
\hline SSR 107 & 10 & $142-168$ & 0.81 & 0.44 & 0.206 & 0.100 \\
SSR 113 & 12 & $207-235$ & 0.87 & 0.40 & 0.255 & 0.046 \\
SSR 323 & 12 & $268-314$ & 0.87 & 0.36 & 0.275 & 0.051 \\
SSR 317-2 & 14 & $112-138$ & 0.88 & 0.64 & -0.037 & 0.039 \\
SSR 156 & 3 & $176-182$ & 0.61 & 0.32 & 0.210 & 0.370 \\
SSR 204 & 4 & $181-189$ & 0.67 & - & - & 0.293 \\
All loci & 55 & - & - & 0.52 & Total & - \\
\hline Mean & 9.16 & - & 0.78 & $1.21 \times 10^{-6}$ \\
\hline
\end{tabular}

genetic parameters such as expected $\left(\mathrm{H}_{\mathrm{e}}\right)$ and observed $\left(\mathrm{H}_{\mathrm{o}}\right)$ heterozygosity, estimated null allele frequency (r) and Probability of Identity (P.I.) are also shown in Table 7. The 25 accessions, which showed different profiles, are characterized by high expected heterozygosity values (from 0.61 to 0.88 ; mean 0.78), compared with observed values (from 0.32 to 0.96 ; mean 0.52) as expected considering that the species studied is an autogamous species. Starting from the genetic similarity coefficients obtained by AFLP and SSR data, a Mantel Test was carried out to test correlation among the two classes of molecular markers. Considering the significant correlation of the Test $\left(\mathrm{R}^{2}=0.89\right)$, a dendrogram was created using the Simple Matching coefficient (SM) and Unweighted Pair-Group Method with Arithmetical Averages (UPGMA) algorithm (Fig. 2) which shows 3 main clusters. The first cluster in the upper part of Figure 2 includes the Italian (3) and Algerian (3) accessions and the Laird tester variety which is found in the same branch of an Italian accession (MG 116219). The second cluster is below the first one and includes accessions from Cyprus $(\mathrm{n}=$ 3), Egypt $(\mathrm{n}=3)$, Libya $(\mathrm{n}=1)$ and Pakistan ( $=1$ ). The third large cluster located in the lower part of Figure 2 has 3 sub-cluster. The upper sub-cluster includes an Ethiopian accession, the 2 ICARDA genotypes and the 2 Moroccan accessions, the central sub-cluster an accession from Pakistan rather similar to 2 Tunisian accessions that may be considered almost synonymous (different name, same genetic profile) as they are different in only $8 \%$ of AFLP and SSR bands analyzed. Finally, the lowest of the 3 sub-clusters includes 2 accessions from
Ethiopia. Therefore, a small number of AFLP and SSR markers are able to highlight clusters that appear to be highly influenced by geographic origins. As expected, genetic distances between accessions are clearly evident and it is possible to distinguish groups of different origin

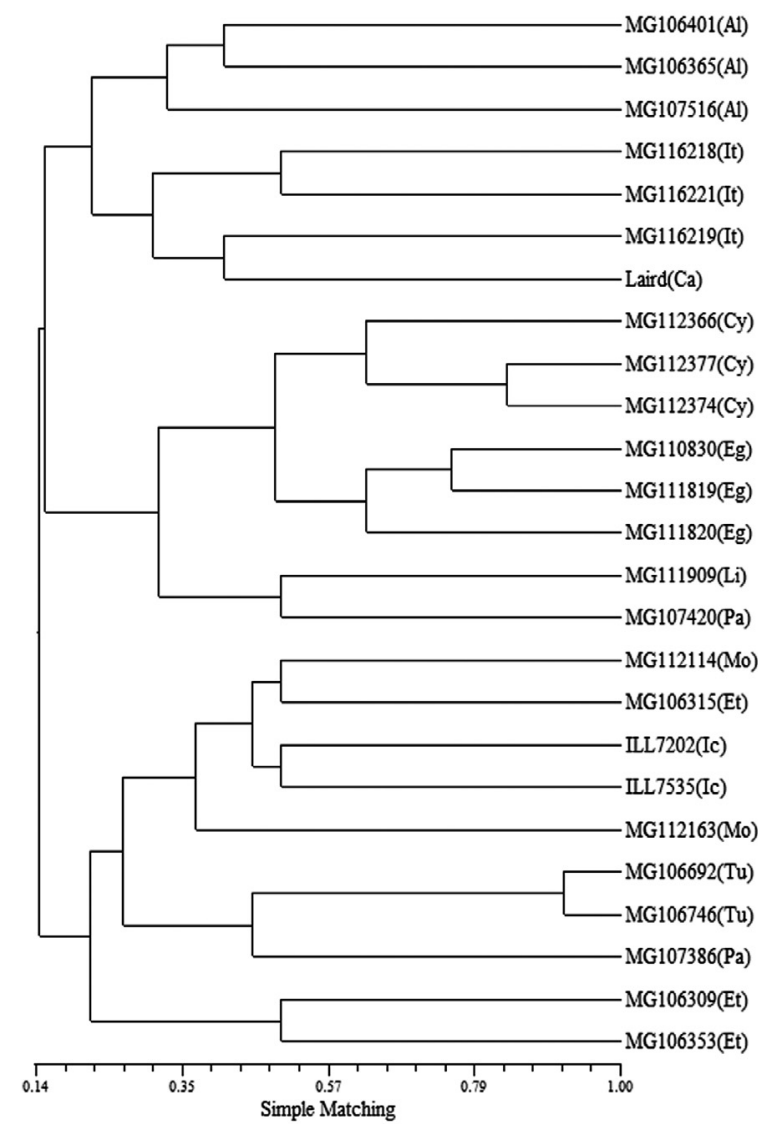

Figure 2. Dendrogram of genetic relationships among 25 lentil accessions utilizing SM coefficients and UPGMA cluster analysis using the SAHN-clustering and TREE program. 


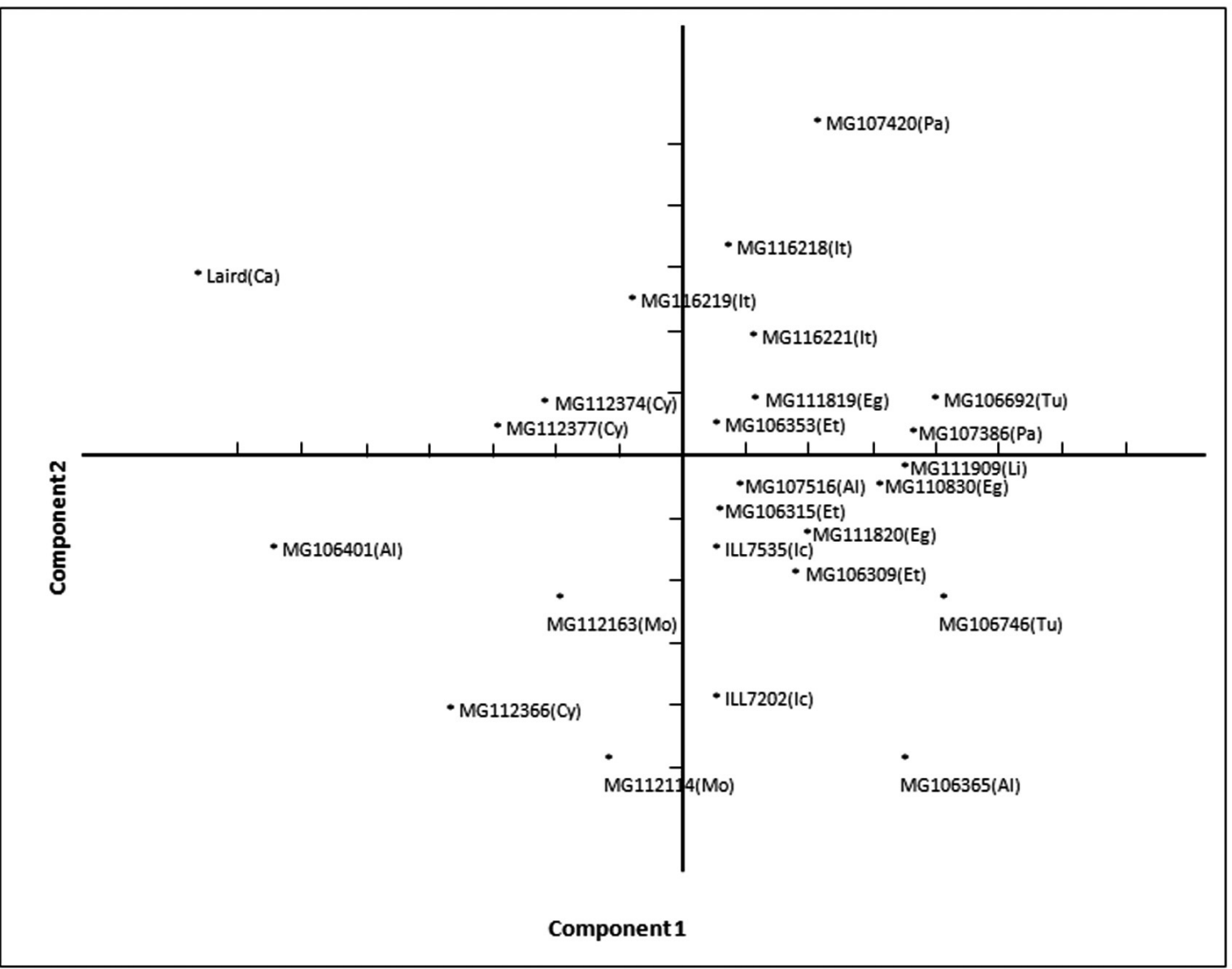

Figure 3. Principal Component Analysis on 25 lentil accessions based on morpho-agronomic and genetic data.

in the Mediterranean Basin. There is a clear genetic relationship between the 3 Italian accessions analyzed and the Algerian accessions, while the Tunisian accessions are not in cluster with the Italo-Algerian group. There is not clear genetic relationship between macro and $\mathrm{mi}$ crosperma accessions in any of the clusters or sub-clusters shown in Figure 2. Principal Component Analysis (PCA) was carried out to describe the distribution of the accessions studied on a plane of Cartesian axes, taking into account genetic as well as morphological and agronomic data. The first two Principal Components (PC1 and PC2) were used to simply describe on a plane the distribution of the 25 accessions analyzed (Eigen values indicated that $89 \%$ of total variability is described by the first two components). The PC1 is mainly affected by pods per plant, while the PC2 is strongly affected by flowering time and 1.000 weight seed. Both the
PCs are not affected by molecular markers data. As a consequence, in the left part of the Figure 3 are positioned all the macrosperma genotypes. The figure also shows the positioning of the Canadian variety, Laird, far from all the other accessions except the Algerian macrosperma (MG 106401), this adjacent sites could be justified by belonging to macrosperma subspecies and by their latest-flowering (the parameters mainly involved in the PC2).

This combined analysis on biodiversity based on morphological and molecular data showed a central area in which are present the accessions from Egypt, Tunisia, Ethiopia and Libya and the others dispersed in the figure with the groups from Italy, Cyprus (two out of three accessions) and Morocco. The information obtained will contribute to future breeding programs in order to obtain well suitable varieties for the Mediterranean environment. 


\section{Conclusion}

The agronomic results highlighted the influence of climatic conditions on phenological, biometrical and yielding traits. Under favourable temperature regime during pod filling, lentil allowed a suitable seed production level, improving pod per plant and 1,000 seed weight. This behaviour confirmed an adaptability to the semi-arid environment of the assessed germplasm. The evaluated landraces over yielded commercial variety Laird, obtained from a breeding program for temperate climate, and the two improved lines from ICARDA.

The negative correlation between earliness and grain yield confirmed even for the lentil the importance of time flowering as effective mechanism of escape from drought; these observations were remarked on all genotypes tested during the field experiments.

The height both of plant and first fertile pod resulted negatively correlated with grain yield, as expected. Pod per plant, positively correlated with grain yield, plays an essential role on the yield determinism in lentil.

The genetic analysis performed by AFLP and SSR markers demonstrated as a small number of AFLP and SSR markers are suitable to describe 3 main clusters highly influenced by geographic origins. The closed genetic relationship between the Italian and the Algerian accessions is not surprising, while it is amazing that the same cluster did not include Tunisian accessions. The genetic analysis shows clearly that clusters are not affected by for agronomic performances. Finally, it is evident that macro and microsper$m a$ groups are not distinguishable with the genetic information collected from AFLP and SSR data.

The PCA analysis that allows to utilize morphological and genetic data, even if confirmed several of the clusters obtained by AFLP and SSR data, showed a different behaviour in the clustering among groups. In particular, it is important to note that the analysis (strongly influenced by important agronomic traits, such as flowering time, pod per plant and 1.000 seed weight) is able to distinguish the macro from the microsperma. The central area of PCA analysis figure showed a similarity among a large group of accessions (small core) and the others were dispersed on the basis of genetic and morpho-agronomic traits. The resulted clustering of accessions jointly with grain yield performances will allow the choice of the best genotypes, not close genetically. On the basis of cluster analysis and PCA, it would be possible to choice parental genotypes for breeding programmes pointed out both genetic distances and most important agronomic traits.

The whole collection of 231 lentil accessions (CNR genebank) have been already characterized in agronomic field experiments, resulting in selected 22 landraces characterized both by agronomic performances and molecular markers in the present first note. A genetic fingerprinting of the whole lentil germplasm collection will be carry out with the aim to include all genetic variability in a defined lentil core collection useful for future breeding programs in semi-arid conditions.

\section{References}

Aggarwal R.K., Shenoy V.V., Ramadevi J., Rajkumar R., Singh L. 2002. Molecular characterization of some Indian Basmati and other elite rice genotypes using fluorescent-AFLP. Theor. Appl. Genet., 105:680-690.

Akkaya M.S., Shoemaker R.C., Spedit J.E., Bhagwat A.A., Cregan P.B. 1995. Integration of simple sequence repeat DNA markers into soybean linkage map. Crop Sci., 35:1439-1445.

Anastasi U., Bacchi M., Monti M., Preiti G. 2007. Valutazione di una collezione di germoplasma di lenticchia (Lens culinaris Medik.) per la valorizzazione dei sistemi colturali delle aree mediterranee. Atti XXXVII Convegno annuale SIA. "Il contributo della ricerca agronomica all'innovazione dei sistemi colturali mediterranei". Catania, 13-14 settembre 2007.

Bacchi M., D’Alessandro F. 1996. Weed control in lentil (Lens culinaris Medik). Proceedings of "Second International Weed Control Congress". Copenaghen, Denmark, 25-28 June 1996.

Di Prima G., Monti M., Preiti G., Laghetti G., Piergiovanni A.R. 1997. Caratterizzazione agronomica e qualitativa di germoplasma di lenticchia (Lens culinaris Medik). Risultati preliminari. Atti del $3^{\circ}$ Convegno Nazionale sulla Biodiversità, 16-17 giugno 1997, Reggio Calabria, 271-277, Laruffa Editore, Reggio Calabria.

Doyle J.J., Doyle J.L. 1987. A rapid DNA isolation procedure for small quantities of fresh leaf tissue. Phytochem. Bull., 19:11-15.

Duràn Y., Fratini R., Garcìa P., Pérez de la Vega M. 2004. An intersubspecific genetic map of Lens. Theor. Appl. Genet., 108:1265-1273. 
Erskine W. 1997. Lessons for breeder from landraces of lentil. Euphytica, 93:107-112.

Eujayl I., Baum M., Erskine W., Pehu E., Muehlbauer F.J. 1997. The use of RAPD markers for lentil genetic mapping and the evaluation of distorted $\mathrm{F}_{2}$ segregation. Euphytica, 96:405-412.

Eujayl I., Baum M., Powell W., Erskine W., Pehu E. 1998. A genetic linkage map of lentil (Lens spp.) based on RAPD and AFLP markers using recombinant inbred lines. Theor. Appl. Genet., 97: 3-89.

FAOSTAT 2007, 2008. Food and Agricultural Organization, Statistical Databases, www.fao.org.

Fiocchetti F., Laddomada B., Roselli M., Crinò P., Lucretti S. 2009. Fingerprinting of three typical macrosperma Italian lentil (Lens culinaris Medik.) landraces using fluorescence-based AFLP markers. Scientia Hort., 121:383-387.

Gallo L., Piergiovanni A.R., Lioi L., Santonicola L., Magnifico V. 2009. Il recupero di un prestigioso ecotipo calabrese: la lenticchia di Mormanno. Ital. J. Agron., 4 suppl.:333-338.

Graham P.H., Vance P.C. 2003. Legumes: Importance and Constraints to Greater Use. Plant Physiol., 131:872877.

Gresta F., Avola G., Abbate V. 2009. Caratterizzazione morfo-bio-agronomica di ecotipi siciliani di leguminose da granella minori. Ital. J. Agron., 4 suppl.:349354.

Gupta M., Chyi Y.-S., Romero-Severson J., Own J.L. 1994. Amplification of DNA markers from evolutionarily diverse genomes using single primers of simple sequence repeats. Theor. Appl. Genet., 89:9981006.

Hamann A., Zink D., Nagl W. 1995. Microsatellite fingerprinting in the genus Phaseolus. Genome, 38:507-515.

Hammer Ø., Harper D.A.T., Ryan P.D. 2001. Past: Paleontological Statistics Software Package for Education and Data Analysis. Palaeontologia Electronica, 4, 1, art. 4:9 pp.

Hamwieh A., Udupa S. M., Choumane W., Sarker A., Dreyer F., Jung C., Baum M. 2005. A genetic linkage map of Lens sp. based on microsatellite and AFLP markers and the localization of fusarium vascular wilt resistance. Theor. Appl. Genet., 110:669-677.

Howieson J.G., O’Hara G.W., Carr S.J. 2000. Changing roles for legumes in Mediterranean agriculture: developments from an Australian perspective. Field Crops Research, 65:107-122.

Ladizinsky G. 1993. Wild lentils. Crit. Rev. Plant Sci., 12:169-184.

Laucou V., Haurogné K., Ellis N., Rameau C. 1998. Genetic mapping in pea. 1 . RAPD-based genetic linkage map of Pisum sativum. Theor. Appl. Genet., 97:905-915.

Mantel N. 1967. The detection of disease clustering and a generalized regression approach. Cancer Res., 27:209-220.
Mayer M.S., Soltis P.S. 1994. Chloroplast DNA phylogeny of Lens (Leguminosae): origin and diversity of the cultivated lentil. Theor. Appl. Genet., 87:773-781.

Monti M., Preiti G., D’Alessandro F. 1995. Correlation and path analysis in italian landraces of lentil (Lens esculenta Moench): preliminary results. Proceedings of $2^{\text {nd }}$ European Conference on Grain Legumes "Improving production and utilisation of grain legumes", 9-13 July, Copenhagen, Denmark.

Monti M., Preiti G., Di Prima G., Perrino P. 1999. Valutazione di germoplasma di lenticchia: analisi della variabilità dei caratteri morfobiologici ed agronomici. Atti del $5^{\circ}$ Convegno Biodiversità, Caserta, 9-10 Settembre, 550-555.

Morgante M., Olivieri A.M. 1993. PCR-amplified microsatellites as markers in plant genetics. Plant J., 3:175-182.

Pacucci G., Troccoli C., Leoni B. 2009. Valutazione di germoplasma autoctono pugliese di cece (Cicer arietinum L.). Ital. J. Agron., 4 suppl.:691-697.

Piergiovanni A.R. 2000. The evolution of lentil (Lens culinaris Medik.) cultivation in Italy and its effects on the serviva of autochthonous population. Genet. Resourc. Crop Evol., 47:305-314.

Piergiovanni A.R., Santantonio M., Lioi L. 2009. La lenticchia di Villalba: caratterizzazione di uno storico agro-ecotipo siciliano. Ital. J. Agron., 4 suppl.:437-442.

Powell W., Machray G.C., Provan J. 1996. Polymorphism revealed by simple sequence repeats. Trends Plant Sci., 1:215-222.

Preiti G., Pellicanò A., Anastasi U., Monti M. 2009. Effetti dell'epoca di semina e del genotipo sul comportamento bioagronomico della lenticchia in ambiente mediterraneo. Ital. J. Agron., 4 suppl.: 729-735.

Rohlf F.J. 1998. Numerical Taxonomy and Multivariate Analysis System Ver. 2.02. Applied Biostatics Inc., New York.

Rowland L.J., Nguyen O. 1993. Use of PEG for purification of DNA from leaf tissue of woody plants. BioTechniques, 14:735-736.

Rubeena, Ford R., Taylor PWJ. 2003. Construction of an intraspecific linkage map of lentil (Lens culinaris ssp. culinaris). Theor. Appl. Genet., 107:910-916.

Santra D.K., Tekeoglu M., Ratnaparkhe M., Kaiser W.J., Muehlbauer F.J. 2000. Identification and mapping of QTLs conferring resistance to ascochyta blight in chickpea. Crop Sci., 40:1606-1612.

Sonnante G., Pignone D. 2001. Assessment of genetic variation in a collection of lentil using molecular tools. Euphytica, 120:301-307.

Sonnante G., Pignone D. 2007. The major Italian landraces of lentil (Lens culinaris Medik.): Their molecular diversity and possible origin. Genet. Resour. Crop Evol., 54:1023-1031.

Tallarico R., Ghiselli L., Pardini A. 2003. La produzione biologica della lenticchia nel Mugello. Agroindustria 2, 1:37-42. 
Venora G., Grillo O., Shahin M.A., Symons S.J. 2007. Identification of Sicilian landraces and Canadian cultivars of lentil using an image analysis system. Food Reser. Intern., 40:161-167.

Vos P., Hogers R., Bleeker M., Reijans M., van de Lee T., Hornes M., Frijters A., Pot J., Peleman J., Kuiper M., Zabeau M. 1995. AFLP: a new technique for DNA fingerprinting. Nucleic Acids Res., 23:44074414.

Wagner H.W., Sefc K.M. 1999. IDENTITY 1.0. Centre for Applied Genetics, University of Agricultural Sciences, Vienna.

Webb C., Hawtin G. (eds.) 1981. Lentils. Commonwealth Bureau, Page Bros, Norwich.

Welsh J., McClelland M. 1990. Fingerprinting genomes using PCR with arbitrary primers. Nucleic Acids Res., 18:7213-7218.

Williams J.G.K., Kubelik A.R., Livak K.J., Rafalski J.A., Tingey S.V. 1990. DNA polymorphisms amplified by arbitrary primers are useful as genetic markers. Nucleic Acids Res., 18:6531-6535.

Yu KF., Park SJ., Poysa V., Gepts P. 2000. Integration of simple sequence repeat (SSR) markers into a molecular linkage map of common bean (Phaseolus vulgaris L.). J Hered., 91:429-434.

Zàvodnà M., Kraic J., Paglia G., Gregov E., Morgante M. 2000. Differentiation between closely related lentil (Lens culinaris Medik.) cultivars using DNA markers. Seed Sci. Technol., 28:217-219. 